\title{
Geografski prostor in turistična politika
}

\author{
Marjan Tkalčič \\ Mag., Turistica - Visoka šola za turizem, Obala 29, 6320 Portorož, Slovenija \\ e-mail: marjan.tkalcic@turistica.edu
}

\section{Izvleček}

Turizem trži poleg storitev turističnih organizacij tudi geografski prostor $v$ širšem smislu besede (prostor, naravne vrednote, kulturno dediščino, kvaliteto življenja prebivalstva, organiziranost družbe itd.). Množica različnih delnih turističnih proizvodov, identiteta kraja in njegovi razpoložljivi resursi tvorijo celoviti turistični proizvod destinacije. Usklajeno delovanje zasebnega in javnega sektorja turistične destinacije kot sistema zagotavlja turistična politika.

Klučne besede: geografski prostor, turistična destinacija, celoviti turistični proizvod, turistična politika

\section{Geographic Space and Tourism Policy}

\begin{abstract}
Apart from other tourist services tourism also markets geographic space in its broader sense, e.g. environment, natural beauties, cultural heritage, the life quality of local inhabitants, the organisation of the society, etc. The final product offered by a tourist destination consists of a variety of products, the identity of the destination and all the resources available. Tourism policy makes it possible for the private and public sector of the tourist destination to be brought into accord.
\end{abstract}

Key words: geographic space, tourist destination, total product of destination, tourism policy 


\section{UVOD}

Turizem opredeljuje široka paleta pojavov in akterjev ter njihovih medsebojnih odnosov, povezanih s povpraševanjem in ponudbo storitev na turističnem trgu in v konkretnem geografskem prostoru (okolju). Predpogoj za nastanek oz. razvoj turizma in z njim povezanih dejavnosti je obstoj turističnega povpraševanja (potencialnega in realnega) na eni strani (emitivno turistično območje) ter turističnih privlačnosti in ustrezen management le-teh na drugi strani (receptivno turistično območje oz. turistična destinacija). Vprašanja in problemi turističnega povpraševanja nas v pričujočem prispevku ne zanimajo.

Turistična dejavnost kot sestavljena gospodarska dejavnost, obsega poleg osnovnih turističnih dejavnosti (dejavnosti gostinskih prehrambenih in nastanitvenih obratov ter organiziranja in prodaje turističnih potovanj) tudi dopolnilne turistične dejavnosti (igralništvo, zabava, kongresi, prireditve, rekreacija itd.), ter dejavnosti javnega turističnega sektorja (turistična promocija, kakovost okolja, zagotavljanje informacij in tehnične pomoči turistom itd.). Neposredni in posredni učinki turizma so očitni tudi v drugih gospodarskih (promet, trgovina, kmetijstvo, živilska industrija, obrtne storitve, komunalne dejavnosti, bančništvo, zavarovalništvo itd.) in negospodarskih dejavnostih (kultura, šport, zdravstvo, znanost, izobraževanje itd.). Pri tem ne smemo spregledati povratnega vpliva in učinkov teh dejavnosti (gospodarskih in negospodarskih) na turizem.

Poleg storitev in blaga, ki jih na turističnem trgu ponujajo zgoraj navedene turistične in s turizmom povezane dejavnosti (sekundarna turistična ponudba), trži turizem tudi prostor oz. okolje v širšem smislu besede (naravne vrednote, kulturno dediščino, kulturno krajino, kvaliteto življenja prebivalstva, organiziranost države in lokalne skupnosti ter njen odnos do okolja in do gostov - turistov itd.). Le-to (okolje $v$ širšem smislu besede) kot osnovna turistična privlačnost, je podlaga in pogoj za razvoj sekundarne turistične ponudbe. Obstoj oz. delovanje le-te povratno vpliva na osnovne turistične privlačnosti in jih spremeni v primarno turistično ponudbo, s čimer se ponudba neke geografske regije zaokroži in oblikuje $\mathrm{v}$ turistično destinacijo kot cilj potovanja turistov.

\section{TURISTIČNA DESTINACIJA KOT OSNOVNA CELICA TURISTIČNEGA TRGA}

Osnovna celica turističnega trga ni posamični (delni) proizvod ampak destinacija s svojim celovitim (integralnim) proizvodom, ki ga sestavljajo osnovne turistične privlačnosti ter turistične in s turizmom povezane dejavnosti. 
Tako kot je turizem sestavljena dejavnost je tudi njen »proizvod « vedno bolj sestavljen iz večih delnih proizvodov, ki povezani v celoto, predstavljajo integralni (sestavljeni, celoviti) turistični proizvod. Planina (1997) navaja, da je kakovost integralnega turističnega proizvoda večinoma odvisna od tistega delnega proizvoda, ki ima najslabšo kvaliteto. Turisti kot potrošniki poznajo posamezne delne proizvode in tudi njihovo kakovost. Kakovost integralnega proizvoda pa največkrat zelo subjektivno ocenjujejo po kakovosti delnega proizvoda, s katerim so bili najmanj zadovoljni.

Predstava turistov o turistični destinaciji se spreminja in zori na podlagi razvoja njene medijske podobe in spreminjanja motivov ter potreb turistov. Turisti pred obiskom, na podlagi predstav (o različnih destinacijah), opravijo izbiro; med obiskom in ob izpolnitvi (uresničitvi) obljubljenih storitev preverijo njihovo korist(nost) - »value for money«; po obisku pa so te izkušnje podlaga za njihovo bodoče potrošniško obnašanje in odločanje.

Turistična destinacija je prostor, kjer se srečujeta turistično povpraševanje (potrebe in pričakovanja ter predstave turista o destinaciji) na eni, in turistična ponudba (integralni in posamični turistični proizvodi) na drugi strani. Ta prostor (destinacija) ima, gledano $\mathrm{z}$ enega ali $\mathrm{z}$ drugega zornega kota, zelo različne forme in dimenzije.

Manente in Cerato (2000) ugotavljata, da ima pojem »turistična destinacija « lahko različne razlage in pomene glede na zorni kot opazovanja (ekonomski, marketinški, geografski, sociološki, itd.). Opredelitev destinacije je v odvisnosti od množice dejavnikov (lokalne zasebne turistične dejavnosti, javni lokalni dejavniki, zunanji - ne lokalni - dejavniki, gostiteljska-lokalna skupnost) in predstav (potencialno in realno turistično povpraševanje).

Če združimo različne predstave in izkušnje turistov z množico sestavljenih turističnih proizvodov in z identiteto kraja ter njegovimi razpoložljivimi viri, lahko razumemo destinacijo kot sistem. Sistem pa je potrebno organizirati in upravljati. Potreba po dobri, uspešni in učinkoviti organiziranosti ter managementu destinacije je na lokalni ravni najpomembnejša saj se turist $\mathrm{z}$ njo (organiziranostjo in upravljanjem) ter $\mathrm{z}$ učinki njenega delovanja, srečuje praktično na vsakem koraku in $\mathrm{v}$ vsakem trenutku njegovega bivanja $\mathrm{v}$ tej destinaciji.

Laws (1995) opredeljuje turistično destinacijo kot skupino med seboj povezanih dejavnikov (preko vzajemnih odnosov urejenih s posebnimi pravili), kjer dejavnost vsakega posameznika vpliva na dejavnost drugih, zato morajo biti skupni cilji opredeljeni in doseženi na koordiniran način. 
Slika 1: Turistična destinacija kot hierarhični sistem in turistično tržišče

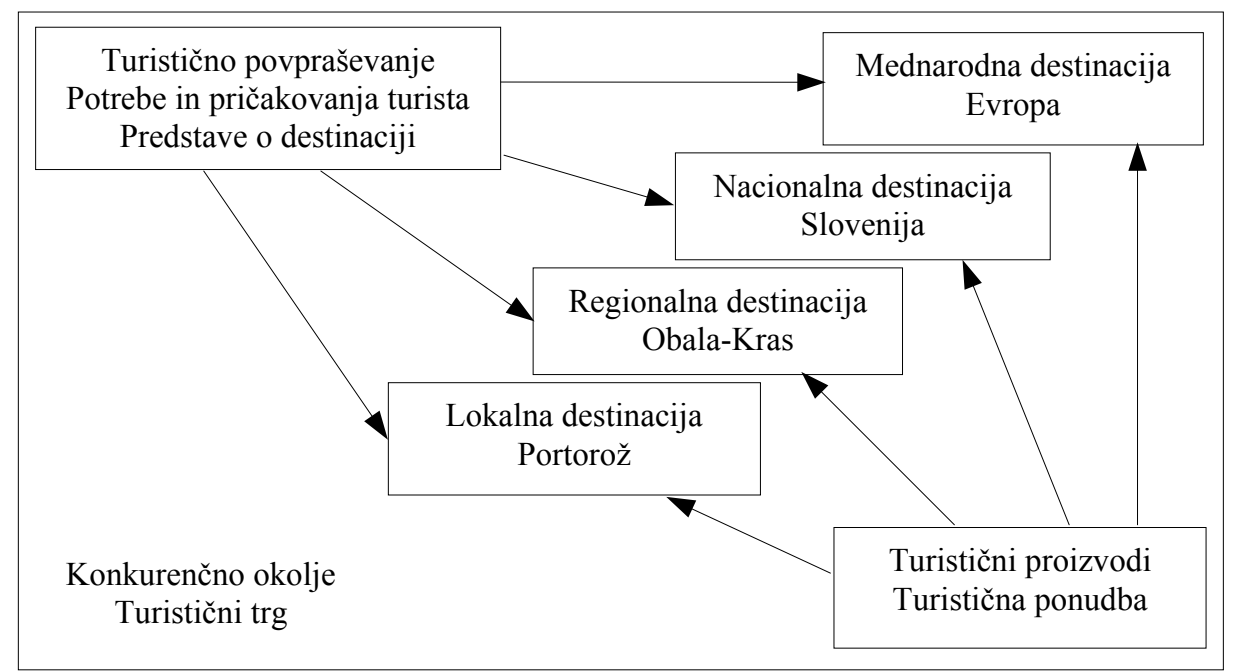

\section{POLITIKA - TURIZEM - GEOGRAFSKI PROSTOR}

Splošni cilj turistične destinacije, dvig kakovosti turističnih storitev destinacije, je možno doseči samo z usklajenim delovanjem javnega in zasebnega sektorja ter s soodgovornim, aktivnim sodelovanjem vseh vključenih akterjev. Opredeljevanje in določanje skupnih ciljev destinacije ter poti in sredstev za njihovo udejanjanje je stvar turistične politike kot sestavnega dela splošne gospodarske politike. S tem lahko pomembno prispeva $\mathrm{k}$ oblikovanju in realizaciji splošnih ciljev gospodarske politike neke regije oz. države (uspešnost gospodarstva, ekonomska blaginja prebivalstva, razvoj, stabilnost, zaposlovanje itd.). Nujnost prisotnosti politike v turizmu utemeljujeta Sancho (1998) in Fajos-Solá (2001) z dejstvom, da je turizem kompleksen ekonomski, socialni in prostorski pojav ter $\mathrm{z}$ naslednjimi argumenti:

- Osnovne turistične privlačnosti (naravni in kulturni spomeniki, vodne površine in obale, gore, čist zrak itd.) so praviloma javna dobrina;

- Veliko družbenih (negospodarskih) dejavnosti je vključenih v integralni turistični proizvod (muzeji, galerije, zdravstvo, komunalne dejavnosti itd.), njihovo financiranje pa $\mathrm{v}$ glavnem zagotavljajo javne finance - proračun;

- Turizem je veliki uporabnik prostora. Nenadzorovana raba prostora s strani zasebnih ponudnikov posameznih turističnih proizvodov lahko privede do ekstraprofita na strani kapitala in do velikega družbenega stroška javnega sektorja na drugi strani. 
Pri kreiranju strategije turističnega razvoja mora turistična politika upoštevati splošne zahteve turističnega načrtovanja in si zastaviti naslednje cilje:

- Prilagajanje turističnih proizvodov (ponudbe) novim potrebam in zahtevam trga (upoštevanje sodobnih trendov povpraševanja);

- Zagotavljanje kakovosti storitev;

- Ustvarjanje pogojev za jačanje podjetniškega povezovanja (mreža podjetij);

- Diverzifikacija turistične ponudbe;

- Prostorska in časovna dekoncentracija turistične ponudbe.

Paradoks povratne zveze med turizmom in osnovnimi privlačnostmi je rezultat nasprotja interesov med zasebnim sektorjem (profit na kratki rok) in javnim sektorjem (zagotavljanje možnosti razvoja na dolgi rok). Bodlender (1991) trdi, da je uspešna tista turistična politika, ki minimizira zgoraj omenjeni konflikt in razvije takšen model organiziranja turizma, ki bo omogočal normalno delovanje zasebnega sektorja.Pri tem mora turistična politika zagotoviti uveljavljanje treh ključnih pogojev trajnostnega razvoja na področju turizma:

- Varovanje naravnega okolja;

- Upoštevanje lokalne družbe in spoštovanje njenih kulturnih vrednot;

- Uspešnost turističnega produkta na srednji in dolgi rok.

Posebno pozornost mora turistična politika posvetiti razvoju in aktiviranju modernih turističnih resursov (inovativnost in intelektualno moč timov v organizacijah, strateški management informacij in znanja ter organizacijsko kulturo skupnosti).

Za gospodarsko politiko je na področju odpiranja novih gospodarskih možnosti in vzpodbujanju regionalnega razvoja izrednega pomena vloga turizma pri prerazporejanju družbenega bogastva, zlasti pri »prenosu« delovnih mest in dohodka iz gospodarsko uspešnih $\mathrm{v}$ problematična, pretežno ruralna območja ter $\mathrm{v}$ industrijsko in rudarsko izčrpana območja. Na ta način lahko turizem prispeva $\mathrm{k}$ boljši izrabi ruralnih regij, $\mathrm{k}$ odpiranju novih delovnih mest in ohranjanju poselitve na območjih depopulacije, $\mathrm{k}$ ohranjanju kulturne krajine in $\mathrm{k}$ revitalizaciji propadajočih vasi in k novemu zagonu (prestrukturiranju) nazadujočih tradicionalnih industrijsko-rudarskih regij.

\section{ZAKLJUČEK}

Turizem je v zadnjih desetletjih doživel velike spremembe na področju turističnega povpraševanja (porast turističnih tokov, spremenjeni interesi, motivi in pričakovanja turistov itd.) in ponudbe (organiziranost ponudnikov, zavedanje nujnosti sožitja med varovanjem naravnih vrednot in kulturne dediščine ter identitete skupnosti na eni strani in turistične rabe na drugi strani itd.). Global- 
no vzeto se potencialno turistično povpraševanje hitro povečuje, podobno velja tudi za realno turistično povpraševanje, toda le-to se lahko hitro zmanjša (za neko konkretno turistično destinacijo) iz različnih razlogov. Med možnimi razlogi je tudi vprašanje učinkovitosti organiziranosti oz. kvalitete turistične politike destinacije ter njenega odnosa do zgoraj omenjenih treh aspektov trajnostnega razvoja turizma.

Izhodišče strateške turistične politike je turistična destinacija (kraj, regija, država) kot skupina med seboj povezanih dejavnikov (preko vzajemnih odnosov določenih s posebnimi pravili), kjer dejavnost vsakega posameznika vpliva na dejavnost drugih, kjer so določeni skupni cilji, ki morajo biti opredeljeni in doseženi na koordiniran način. Tiste destinacije, ki na svetovnem turističnem trgu nastopajo s pomočjo (na podlagi) strateške turistične politike se veliko bolje obnesejo (so bolj konkurenčne) kot tiste destinacije kjer je tovrstna intervencija oblasti (državne, regionalne ali lokalne) odsotna.

\section{Viri:}

Bodlender, J. et al., 1991. Developing Tourism Destination. Harlow, Longman.

Fayos-Solá, E., 2001. NO STATE, NO TOURISM: The Need for Governmental And Intergovernmental Organizations in the New Age of Tourism. V: Wahad, S., Cooper C. (urednika), Tourism in the age of globalization, London, Routledge.

Laws, E., 1995. Tourist destination management: issues, analysis and policies. London, Routledge, 37.

Manente, M., Cerato, M., 2000. Destination Management per creare valore. V: Pechlaner, H., Weiermair, K. (urednika), Destination Management, Milano, Touring Editore, 55-72.

Planina, J., 1997. Ekonomika turizma. Ljubljana, UL Ekonomska fakulteta, 206.

Sancho, A., Buhalis, D., Gallego, J., Mata, J., Navarro, S., Osorio, E., Pedro, A., Ramos, S., Ruiz, P., 1998. Introducción al Turismo, Madrid, Organización Mundial del Turismo (OMT), 164.

\section{GEOGRAPHIC SPACE AND TOURISM POLICY}

\section{Summary}

Tourism is defined by a whole range of phenomena, institutions and their relationships and all of them are connected to demand and supply on the tourism market in a certain geographic space. In addition to services and goods offered 
by the tourism and tourism-related industries, the tourism industry markets also geographic space or more precisely the environment in its broader sense, e.g. natural beauties, cultural heritage, landscape, the quality of life, the organisation of the country and local communities together with their attitudes to the environment and tourists. Geographic space as a tourist attraction is the basis and the precondition for the development of tourism and the services it offers.

The product offered is not a single product, but a sum of the products in a tourist destination, such as attractions and services offered by the tourism industry, other tourism-related industries and the public sector. A destination is a place where demand (needs and expectations) and supply (integral and single products) meet.

If a tourist destination aims to reach the higher level of service quality, it can be done only with a close co-operation between the private and public sector.

It is considered that the involvement of politics in tourism is unavoidable, on the one hand, because of its complexity; it is an economic, social and geographic phenomenon. And on the other hand because of the following three facts:

- basic tourist attractions (natural and cultural attractions, waters, shores, mountains and clean air) are the property in public domain;

- a lot of non-commercial activities are included in the product (museums, galleries, health care, waste management and such), their funding is the concern of public finance;

- tourism is closely related to space. The uncontrolled use of space by private sector can lead to excess profit in the private sector and high costs in the public sector.

At the same time tourism policy has to take into account the following three aspects of sustainable tourism development:

- respect for natural environment;

- respect for local communities and their cultural values;

- long-term success of the product.

The role tourism plays in the distribution of national wealth is of crucial importance for economic policy and regional development. It opens up new economic opportunities and adds to job creation and income generation in problematic rural (also mining) areas.

Those destinations offered on the tourism market that are boosted by strategic tourism policy can compete much better than the destinations without the support of the government. 